UDK: $28-1$

DOI: $10.33669 / \mathrm{KJ} 2021-32-03$

primljeno / received: 29. 9. 2021.

prihvaćeno / accepted: 20. 11. 2021.
Izvorni naučni rad

\section{Nerma Zaimović}

Univerzitet Gedik u Istanbulu

Cumhuriyet, İlkbahar Sk. No:1, 34876

Kartal/Istanbul

nerma.zaimovic@gedik.edu.tr

\title{
O rukopisu Kitab-i bosnevi iz Zbirke bosanske alhamijado književnosti sa pojedinim arapskim tekstovima
}

Sažetak: Pjesma Kitab-i bosnevi samo je jedna od nekolicine koja predstavlja svojevrsnu kompilaciju moralističkih alhamijado pjesama sakupljenih u jednu Zbirku bosanske alhamijado književnosti sa pojedinim arapskim tekstovima. Cilj je kroz ortografsku i fonetsko-fonološku analizu rukopisa Kitab-i bosnevi, za koji se pretpostavlja da potječe iz XIX stoljeća, utvrditi ortografske osobenosti i pokušati prikazati kako je autor pisao riječi domaćeg porijekla, a kako je bilježio riječi orijentalnog porijekla, odnosno posuđenice koje su preuzete iz arapskog i perzijskog jezika. Detaljnom ortografskom analizom riječi domaćeg i orijentalnog porijekla koje se nalaze u pjesmi Kitab-i bosnevi, a koja je ustvari bečka verzija djela teksta Sehvetul-vusul, autora Omera Hazima Hume, dobili smo jedan precizniji uvid u karakteristike pisanja alhamijado književnosti. Riječi orijentalnog porijekla bilježile su se tako što se poštovao njihov način pisanja u odnosu na jezik izvornik. U određenim primjerima došlo je do odstupanja, gdje je autor ponudio sasvim jedan drugačiji način bilježenja određenih glasova. $\mathrm{Na}$ osnovu fonetsko-fonološke analize pjesme Kitab-i bosnevi utvrđeno je da su određeni glasovi u potpunosti prilagođeni fonetskom sistemu bosanskog jezika.

Ključne riječi: alhamijado, Kitab-i bosnevi, XIX stoljeće, fonetsko-fonološka analiza 


\section{Uvod}

Arapsko pismo kao pismo arapskog jezika, odnosno arebica, prošla je kroz određene faze adaptacije prema potrebama glasovnog sistema jezika koji su ga preuzimali, odnosno koristili u pisanoj formi prilikom iščitavanja različitih rukopisa i dokumenata. Prva upotreba arapskog pisma u Bosni odnosi se na tekstove koji su bili napisani na osmanskom turskom jeziku, administrativnog karaktera, kao što su sidžili, vakufname, razni defteri, administrativne odluke, rješenja, poreske te matične knjige (Huković 1986: 18), namijenjeni za potrebe komunikacije sa domaćim stanovništvom. Međutim, arapsko pismo kroz svoje postojanje na tlu naše zemlje prošlo je kroz nekoliko perioda prilagođavanja bosanskom jeziku. U jednom od najranijih perioda pokušaja prilagođavanja jezika dešavalo se da su riječi na našem jeziku napisane po onim pravilima koja su se odnosila na pravila i upotrebu arapskog pisma u turskom jeziku (Baćićanin 2016: 57). Međutim, vremenom je iščezla nejednakost $\mathrm{u}$ (ne)pravilima koji je svaki autor iznalazio ponaosob, te se $u$ jednom periodu počela javljati usklađenost $u$ pisanju određenih glasova u jeziku tog perioda. O prilagođavanju arapskog pisma bosanskom jeziku, kao i o tome da je nemoguće koristiti jedno takvo pismo u našem jeziku a da se ne prilagodi glasovnom sistemu, u svojim radovima pisao je istaknuti filolog i arabist Teufik Muftić (Baćićanin 2016: 58).

\section{O rukopisu Kitab-i bosnevi}

Rukopis Kitab-i bosnevi za koji se pretpostavlja da potječe iz XIX stoljeća samo je jedan od mnogobrojnih koji predstavlja svojevrsnu kompilaciju moralističkih alhamijado pjesama sakupljenih u Zbirku bosanske alhamijado književnosti sa pojedinim arapskim tekstovima. Zbirka se nalazi u Nacionalnoj biblioteci u Beču pod registarskim brojem 1681. Na zadnjoj stranici ove zbirke nalazi se i godina 1901. koja je vjerovatno i godina završetka zbirke koja sadrži mnoštvo pjesama, vjerskih uputa, dova. Iz rukopisa koji je napisan na njemačkom jeziku da se zaključiti da je prepisivač ove zbirke Ibrahim Šehović, dok se zbirka nalazi u vlasništvu Abdullaha Abdovića. Nažalost, o autoru, odnosno prepisivaču 
zbirke nismo našli nikakve podatke. Na zadnjoj stranici zbirke od stotinjak stranica nalazi se datum 22. 5. 78. Moralistička pjesma Kitab-i bosnevi je ustvari bečka verzija dijela teksta Sehletul-vusul koji je napisao Omer Hazim Humo. Bečka verzija se od originalne verzije razlikuje po drugačijem bilježenju određenih glasova, kao i zbog redoslijeda riječi u rečenici kod pojedinih primjera. Pismo je rika, lijep, krupniji rukopis. $\mathrm{Na}$ marginama se rjeđe nalaze bilješke u vezi sa tekstom djela. Papir je žućkast, listovi rukopisa nisu oštećeni.

\section{Grafijska struktura pjesme Kitab-i bosnevi}

Pjesma Kitab-i bosnevi samo je jedna od nekolicine alhamijado pjesama koje se nalaze u medžmui pod nazivom Zbirka bosanske alhamijado književnosti sa pojedinim arapskim tekstovima. Ova pjesma predstavlja svojevrsnu kompilaciju moralističkih pjesama koje se svrstavaju u alhamijado književnost i nalazi se od 50. do 66. str. medžmue koja je napisana arapskim pismom. $U$ ovom radu dužni smo spomenuti jedan veoma interesantan detalj koji se odnosi na način bilježenja stranica, odnosno dodavanja nekih riječi ili rečenica u tekst. Pjesma Kitab-i bosnevi se nalazi u medžmui od 50. do 66. str., ali na stranicama pjesme od samog početka do kraja u gornjem lijevom uglu može se primijetiti da su na stranicama naknadno upisivani brojevi tih istih stranica običnom olovkom. Original ovog rukopisa je čitljiv, na nekim stranicama naknadno su se dodavale zaboravljene rečenice od strane autora ili prepisivača, dok se na nekim stranicama mogu uočiti naknadno dodavane riječi hemijskom olovkom ili pak tintom, a na nekim stranicama i običnom olovkom. U transkripciji pjesme, u fusnotama, naznačeni su oni dijelovi koji su se naknadno dodavali. Naknadno dodavanje posebno se odnosi na posljednju stranicu pjesme gdje su se dodavali salavati, odnosno dove.

Prilikom rada na transkripciji pjesme Kitab-i bosnevi uvidjeli smo da je sam rukopis koji je napisan arapskim pismom bez dijakritičkih znakova (tački, crtica), što znači da suglasnici, kao i dugi vokali i diftonzi (primarni grafijski znaci) imaju svoju oznaku, dok to nije slučaj sa 
kratkim vokalima. Samo na nekoliko mjesta se dešavalo da zbog nečitko napisanih grafema imamo poteškoće prilikom iščitavanja određenih grafema, a samim time i riječi. Na nekoliko mjesta mogli smo uočiti i sekundarne grafijske znake kojima su bilježeni kratki vokali, vjerovatno radi lakše čitljivosti nejasnih mjesta u pjesmi. Glasovi, odnosno konsonanti koji su zastupljeni i u arapskom i u našem jeziku su: $b-\varphi, t-ت$,

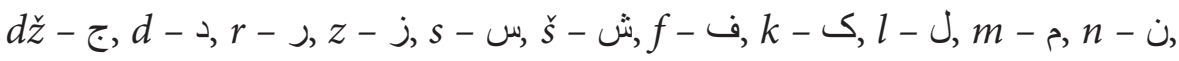
$h-0, j-$ -

$\mathrm{Za}$ one konsonante koji ne postoje $\mathrm{u}$ našem jeziku, a koji se nalaze $\mathrm{u}$ rukopisu Kitab-i bosnevi, bili smo prinuđeni naći odgovarajuće glasove u našem jeziku prilikom transkripcije. Također, dužni smo spomenuti i to da u bosanskom jeziku postoje određeni glasovi kao sto su $c, \check{c}, \dot{c}$, $\downarrow, l j, n j, p, \check{z}$, za koje ne postoji ekvivalenti u arapskom pismu, koje smo također bili dužni prilagoditi glasovnom sistemu bosanskog jezika.

U nastavku je prikazano arapsko pismo prilagođeno fonetskom sistemu bosanskog jezika.

\begin{tabular}{|c|c|c|c|c|c|}
\hline i A, a & $\mathrm{D} \mathrm{D}, \mathrm{d}$ & $\dot{\varepsilon} \mathrm{G}, \mathrm{g}$ & $\mathrm{JL}, 1$ & $\hat{\jmath} \mathrm{O}, \mathrm{o}$ & $ت \mathrm{~T}, \mathrm{t}$ \\
\hline B, b & ج Dž, dž & $\tau \mathrm{H}, \mathrm{h}$ & $\jmath^{\mathrm{Lj}}, \mathrm{lj}$ & 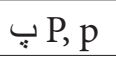 & اؤ U, u \\
\hline ج, c & ج Đ, d & اى I, i & م M, m & \lrcorner $\mathrm{R}, \mathrm{r}$ & $و \mathrm{~V}, \mathrm{v}$ \\
\hline Е Č, č & $\delta \mathrm{E}, \mathrm{e}$ & ي J, j & $ن \mathrm{~N}, \mathrm{n}$ & س S, s & $j Z, z$ \\
\hline جأ Ć, ć & فF, f & ق K, k, Č, 亡 č & $\dot{\mathrm{Nj}}, \mathrm{nj}$ & ش Š, š & jŽ, ž \\
\hline
\end{tabular}

U pjesmi Kitab-i bosnevi grafijska oznaka za $c$ su dvije tačkice (ج), dok se ć označava kvačicom na dolje ili tri tačke (ج), te sa (ك) u određenim primjerima, a č je sa kvačicom okrenutom na gore ili tri tačke (ङ) ili (ق). Pored gore navedenih grafema, koje ne zauzimaju mjesto u arapskom pismu, tu su i $d \check{z}$, odnosno $d$, a za oba glasa koristi se ista grafijska oznaka (ج). U našem jeziku slovo $l j$ označava se sa (ل) u arapskom pismu, a $n j$ koje također ne postoji u arapskom pismu ima grafijsku oznaku kao $n$, samo sa tačkicama (ث). U pjesmi na nekim mjestima glas $n j$ se obilježava i sa dvije tačkice, umjesto sa tri. Glas $p$ koji ne postoji u arapskom pismu u pjesmi Kitab-i bosnevi preuzet je iz perzijskog jezika i označava se kao (ب). Isti slučaj je i sa slovom $\check{z}$ koje ima oznaku (j). 
Pored određenih konsonanata na koje smo posebno obratili pažnju, tu su i određeni vokali koje također trebamo spomenuti u ovom radu. Vokal $a$ se piše onako kako se označava njegova duga varijanta u arapskom jeziku, sa elif(I),(I). Vokal $i$ se označava kao dugi vokal $i$ u arapskom pismu (اى), dok se vokal $o$ i vokal $u$ označavaju isto (او).

\section{Ortografske osobenosti u pjesmi Kitab-i bosnevi}

U ovom se radu namjeravamo bazirati na ortografske osobenosti i pokušati prikazati kako je autor pisao riječi domaćeg porijekla, a kako je bilježio riječi orijentalnog porijekla, odnosno posuđenice koje su preuzete iz arapskog i perzijskog jezika. Pošto o autoru, nažalost, nismo uspjeli naći nikakve podatke, u ovom radu ne možemo tačno precizirati u kojem periodu je djelo nastalo, odnosno koliko je autor odstupao od pravopisa toga vremena. Pravopis klasičnog osmansko-turskog jezika je bio standardiziran na temelju arapskog pisma, te je u 16. stoljeću poprimio klišeiziranu formu i takav se koristio sve do 19. stoljeća (Korkmaz 1995: 483). Ovakav pravopis nije mogao odslikavati promjene, posebno glasovne, koje su se tokom vremena događale u turskom jeziku, gdje vidimo značajne razlike između književnog i narodnog jezika (Filan 2000: 2).

\section{Pisanje riječi domaćeg porijekla}

U bosanskom jeziku postoji pet različitih vokala, a arapsko pismo sadrži samo tri sekundarna grafijska znaka koja je potrebno razlikovati da bi se izbjegle poteškoće i nejasnoće prilikom iščitavanja. Baš iz tog razloga, autori su morali naći način kako bilježiti svaki od tih vokala kako bi čitatelju prenijeli jasnu poruku.

Kod bilježenja riječi domaćeg porijekla, osim nekoliko izuzetaka na koje smo naišli u pjesmi, možemo zaključiti da se nisu koristili sekundarni znaci arapske grafije za označavanje kratkih vokala, dok su kod nekolicine riječi orijentalnog porijekla u pjesmi Kitab-i bosnevi korišteni i primarni i sekundarni grafijski znakovi u bilježenju riječi. Autor ovog rukopisa, odnosno pjesme Kitab-i bosnevi je prilikom bilježenja 
riječi domaćeg porijekla za obilježavanje kratkog vokala $o$ koristio (و) i dammu (') samo na nekoliko mjesta koje smo posebno istakli u radu. Međutim, prema onome što se navodi u knjizi Sehletul-vusul, sva rješenja oko bilježenja vokala i prilagođavanja jeziku nisu ni Humin doprinos, ${ }^{1}$ već su preuzeta ranije, i to iz turskog jezika, gdje se dammom ( $\left.{ }^{9}\right)$ označava kratki vokal o (Drkić - Kalajdžija 2010: 83). Kod riječi domaćeg porijekla može se uočiti veoma jednostavan način bilježenja ovog vokala i to uz pomoć oznake (०). Neki od primjera ${ }^{2}$ su: 25a/2: lijepe (لييهيه), 24b/16: dedovine (ده دووينه), 27a/5: umiješ (اونها) 28b/9: uvesti (اووه ستى), 31b/14: grijehe (غرييهة).

Primjeri na koje smo naišli kod bilježenja riječi domaćeg porijekla u kojima je vidljiva upotreba sekundarnih znakova arapske grafije kod bilježenja kratkih vokala su:

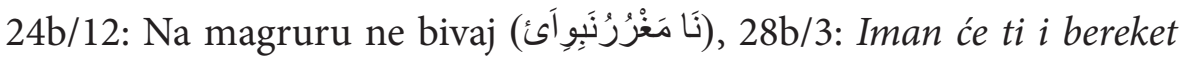

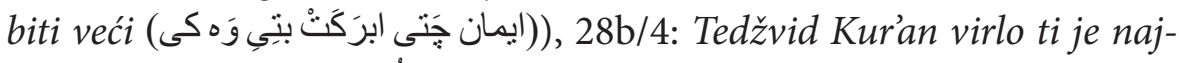

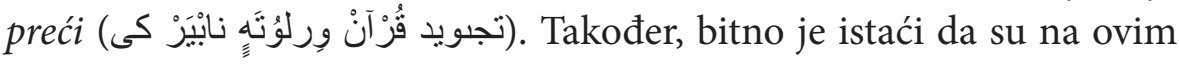
mjestima na kojima su korišteni sekundarni znakovi za označavanje kratkih vokala riječi dosta nečitko napisane uprkos pokušaju autora da olakša njihovo iščitavanje.

U bilježenju dugih vokala kod riječi domaćeg porijekla zabilježen je samo jedan oblik i to znakom elif(') za bilježenje dugog vokala $a$, dok je u bilježenju dugog vokala $u$, kao i vokala $o$ vidljiva kombinacija elif $\mathrm{i}$ vav (او) ako riječ počinje sa nekim od ova dva vokala. U sredini riječi, kao i na kraju, vokal $u$ i vokal $o$ se bilježe samo slovom kojim se inače bilježi konsonant $v($ g). Za bilježenje dugog vokala $i$ korišten je znak za bilježenje konsonanta $j$ (ى), te nerijetko i znak (ب). Neki od primjera iz pjesme Kitab-i bosnevi su: 24a/1: dobar poso (دوبار يوسو) (يوسو), 25a/17: nikoga (نيقوغا), 31b/13: pomozi (يوموزي), 31a/2: u paklu (اوياقو (إ)لو ).

Autor ove pjesme bilježi grafem $l j$ (ل) tačkom s desne strane: 26a/10: ljepota (يوتا لييه), kao i oblikom koji se koristio samo za bilježenje grafema l, s oznakom (ل): 24b/17: ostavljaj (اوستاولایى). Navedeni primjeri

O Omeru Humi i njegovom radu vidjeti: Šabanović 1973; Drkić - Kalajdžija 2010.

2 Za svaki primjer koji je naveden $\mathrm{u}$ analizi na početku se navodi broj lista i reda u tekstu Kitab-i bosnevi. 
pokazuju da je u datom slučaju riječ o mlađem tekstu, jer je u tekstu očit princip obilježavanja palatalnosti koji je preuzet iz drugih bosanskih pisama tog vremena.

Kod bilježenja grafema nj možemo vidjeti da se ipak poštovala ustaljenost jednog od pravila koja su se koristila kako bi se razlikovala dva grafema, tj. $n$ (ن) i $n j$ (ن) : (ناى), 24b/6: klanjaj 27a/18: klanjamo

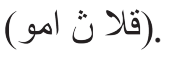

Prilikom pokušaja prilagođavanja arapskog pisma bosanskom jeziku, pored možda i najuobičajenih poteškoća na koje smo nailazili prilikom iščitavanja određenih riječi u kojima su se nalazili grafemi $n, n j$ i $l j$, bez obzira na to da li su se ovi grafemi nalazili na početku ili u sredini riječi, isto tako, s pravom možemo da kažemo da smo imali određenih poteškoća i prilikom iščitavanja grafema koji su bilježeni istom oznakom. Riječ je o grafemima $\dot{c}, \check{c}, d, d \check{z}$.

Kao što smo i prikazali u tabeli ranije, ovi grafemi su se bilježili isto. Tako su grafemi ć i č imali oznaku (ङ) i u nekim primjerima (ك), a $\not$ i $d \check{z}$ oznaku (ج).

Neki od primjera su: 24a/4: počimaj (يوجيماى), 24a/2: učinit (اوجينين), 24b/19: čuvaj (جوواى), 25a/11: faćaj (فایجاى), 24a/21: biće (بيجه), 24b/4: daće (داجه), 25b/5: hoće (حوجه), 28b/3: veći (وهاته), 27a/7: sačuva-

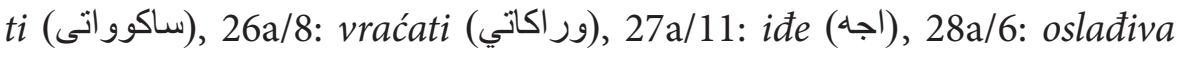
(اوسلاجيوا). U pjesmi nismo naišli na upotrebu grafema $d z ̌$ kod riječi domaćeg porijekla, međutim u poglavlju u kojem su obuhvaćene riječi orijentalnog porijekla naišli smo na mnogo primjera o kojima će biti govora u tom dijelu rada. Tu ćemo prikazati bilježenja grafema $d z ̌$ koji ne čini nikakvu razliku u odnosu na grafem $d$.

U vezi sa pisanjem grafema $t$ naišli smo na nekoliko odstupanja koja ćemo spomenuti u narednim primjerima. Glas $t \mathrm{u}$ većini slučajeva bilježio se oznakom (ت): 24a/5: pamet (تامت), 24b/19: takva (تقو ات), 27a/8: dati (داتى), 30a/19: biti (بتي), dok je kod riječi arapskog porijekla prevladavala upotreba znaka (b).

Za autora ovoga rukopisa možemo reći da je vjerovatno neko sa područja Bosne zbog dobrog poznavanja bosanskoga jezika što se moglo 
vidjeti i kod bilježenja riječi domaćeg porijekla, gdje je autor pažljivo i prezicno bilježio grafeme. Jedan od tih grafema koji se bilježio veoma precizno je svakako i grafem $z(j)$. Kod bilježenja riječi domaćeg porijekla glas $z$ (j) se bilježio na korektan način: 24a/3: jezikom (يزيقوم), 26b/14: znadeš (زناده), 28b/16: zaboga (زابوغاه), 29b/13: zatvoriti (زناه), 31a/4: znah (زناه), dok je kod bilježenja riječi stranog, odnosno orijentalnog porijekla došlo do odstupanja, gdje nerijetko možemo vidjeti različita bilježenja, vjerovatno zbog nedovoljnog poznavanja orijentalnih jezika.

Ono što je veoma bitno naglasiti kod pisanja riječi domaćeg porijekla je i to da je autor u pjesmi Kitab-i bosnevi proklitike i enklitike bilježio sastavljeno sa toničnim riječima, ali prilikom transkripcije odlučili smo da tekst prilagodimo modernim normativnim rješenjima, kao u sljedećim primjerima: 24a/6: ti viruj - tivjeruj (تيويروى), 25b/6: nemoj se - nemojse (نمويسه), 25b/6: ni s kim - niskim (نيسقيم), 25b/10: ti devletu - tidevletu (تي دولنو), 26a/8: grijeh se - grijehse (غربيهن).

U pjesmi nailazimo na primjer kao što je 24a/4: paš (بیش) koji se, kao što smo i vidjeli, bilježi perzijskim grafemom $p(ب)$. Danas, u savremenom bosanskom jeziku, paš se bilježi i izgovara kao baš (باش).

U alhamijado književnojezičkom izrazu, a kako to pokazuje i prisustvo jezičkih osobina ovog teksta, zabilježene su specifične osobine grafijskog bilježenja određenih glasova koje joj daju jedan poseban status književnojezičke koine u okviru predstandardnog bosanskog idioma (Drkić - Kalajdžija 2010: 159). Književnojezička koine predstavlja predstandardni idiom (Kalajdžija 2019: 74), koji ustvari predstavlja svaki oblik književnojezičkog stvaralaštva prije pojave standardnog jezika. Predstandardni idiom u svojoj strukturi posjeduje određene elemente koji ga karakteriziraju i čine prepoznatljivim (Kalajdžija 2019: 199). O tome da alhamijado književnost posjeduje sve predispozicije na osnovu kojih se može označiti posebnim predstandardnim idiomom posebno navodi Kalajdžija (2019: 203-204). U ovom dijelu rada navest ćemo primjere koji upućuju na ikavizam, i to u kratkim slogovima: 30a/18: srića (سريجا), 24 a/11, 12, 26b/13...: nima (نيما). Kod primjera kao što je nima uočljiva je promjena fonema u morfemu, takozvani hiperikavizam. 
Kod bilježenja određenih riječi vidljivo je prisustvo jotovanja u primjerima progresivnog jotovanog d:27a/18: idemo (ايجه مو), 24b/8: iđi (ايجى), te na dva mjesta 27a/15, 27b/6: ide (ايجه), dok je na mjestu 27b/9 bilježeno ide (ايده).

Iz teksta izdvajamo i sljedeće primjere:

Bilježenje glasa $\check{c}$ (ङ) u primjerima u kojima bi trebao stajati glas $t(ت)$ 25a/11: faćaj (فاجایى), odnosno $k$ (ق) 27b/1: pać (باج):

Umjesto grafijom $s$ (س) bilježilo se sa $z(j): 25 a / 17:$ zem (زم).

\section{Bilježenje riječi orijentalnog porijekla}

Na području Balkana, nešto više od 500 godina, vladalo je Osmansko Carstvo čije se prisustvo, upravo zbog svoje dugogodišnje rasprostranjenosti, odrazilo u prvom redu na kulturu, običaje, a potom i na jezik. Svaki dolazak nove vlasti, bez obzira o kojem području i o kojem narodu se radilo, uvijek je sa sobom donosio novitete koji su se miješali sa onim postojećim. Lokalno stanovništvo je prihvatalo nove običaje, kulturu, kao i nove riječi s kojima su se susretali i koje su vremenom postale sastavni dio jezika i života starosjedilaca. Najveći dio arapskih riječi u bosanski jezik prešao je preko perzijskog i turskog, koji su na izgovor tih riječi ostavili utjecaj svoga fonetskog sistema gdje se nerijetko dešavalo da se njihov izgovor u bosanskom jeziku nije poklapao s onim $\mathrm{u}$ arapskom, nego pak sa onim koji je zastupljen u jezicima kao sto su perzijski i turski (Drkić - Kalajdžija 2010: 93). Te riječi koje su bile prihvaćene u našem jeziku prošle su kroz određenu fonetsku adaptaciju dodavanjem određenih sufiksa i nastavile su se koristiti i danas.

Autori koji su rođeni na području koje je bilo pod utjecajem osmanske vladavine u svojim djelima koristili su riječi orijentalnog porijekla, međutim prilikom njihovog pisanja arapskim pismom, autori su imali dosta poteškoća sa pisanjem nekih grafema kojih nema ili nisu mnogo zastupljeni u riječima domaćeg porijekla. U ovom radu bit će govora o tome kako su se bilježile riječi, odnosno pojedini grafemi u riječima orijentalnog porijekla, te koji su to grafemi koji su naši autori najčešće bilježili drugačije u odnosu na njihovo pisanje u izvornom jeziku. 
U transliteraciji ovog rukopisa, ako se uzmu i drugi rukopisi tog perioda, mogu se uočiti primjeri koji imaju nešto drugačiji izgovor u bosanskom jeziku u odnosu na izvorni arapski jezik. Jedan od tih izgovora koji se razlikuje od onoga u izvornom jeziku je glas $z$. Naime, ovaj glas se u arapskom jeziku izgovara sa $\underset{d}{(j)}$, ali u turskom i bosanskom jeziku izgovara se kao $z$, što se može vidjeti u primjerima: heze (هز ( هز (j), 24b/7: ramazan (ماضر (راضان), 25b/16 hazer 29a/1: azab (عزاب).

$\mathrm{U}$ vezi sa pisanjem grafema $t(b)$ naišli smo na nekoliko odstupanja koje ćemo spomenuti u narednim primjerima. Glas $t \mathrm{u}$ većini slučajeva bilježio se oznakom (b), međutim u nekim primjerima došlo je do odstupanja, vjerovatno iz razloga što je autoru bilo strano pisanje ove riječi, s obzirom na to da nije izvorna bosanska riječ. Prilikom iščitavanja pjesme Kitab-i bosnevi uvidjeli smo da prilikom pisanja riječi koje imaju veze sa korijenom riječi Turk (Türk), koja se odnosi na čovjeka vjernika - muslimana, dolazi do odstupanja, odnosno miješanja grafijskih znakova ( oznakom (ط), a na nekim mjestima (توكين): 25b/13: turčin (توركين), 25b/16: turke (توركه), 26a/3: turčin (توركين), 28a/3: turčin (طركين), 29a/7: turčin (تورجين), 30b/1: turci (طورجى), 30b/4: tučin (طورجنين), 30b/10: turci (طورجى), 31a/16: turskom (طورسق)م (طورج).

U ovom radu veoma je bitno naglasiti da je autor ove pjesme riječi orijentalnog porijekla bilježio poštujući njihov način pisanja u jezicima iz kojih vode porijeklo. U trenutku kada taj način bilježenja riječi nije odgovarao fonetskim karakteristikama bosanskog jezika, prednost bi se dala fonetskom sistemu našeg jezika i to samo na kraju riječi i u naglašenim slogovima.

Slijede neka od odstupanja koja su zabilježena u pjesmi Kitab-i bosnevi u odnosu na jezik izvornik.

Umjesto (خ) bilježilo se (ح): 28a/11: hodža (حوجا). Ovdje vidimo da je riječ na dva mjesta napisana drugačije u odnosu na jezik izvornik. Riječ hodža dolazi od perzijske riječi hāâce (خواجه), pa bi u ovom primjeru umjesto (ح) trebalo bilježiti $(\dot{\zeta})$, te umjesto elif (।) samo (॰). 25a/3: huje (حوئه) je isto tako grafijski drugačije bilježena riječ, iz razloga što se riječ huy u perzijskom jeziku obilježava kao (خوى). 
Na nekoliko mjesta umjesto (ح), stoji (خ). Riječ hazer 30a/2 bilježila se (خظر), a u jeziku izvorniku stoji hazır (حاضر). Ovdje možemo vidjeti da su se na nekoliko mjesta grafemi bilježili drugačije. Kod primjera 31b/7: rahat (راخت), drugačije je bilježen glas (ح). U jeziku izvorniku ova riječ se bilježila (راخت). U jednom primjeru vidi se (o), umjesto (ح): 29a/12: hesab (هساب). Umjesto (حساب) (حساب) u pjesmi se koristilo (o), što je drugačije u odnosu na jezik izvornik.

Vrlo rijetko, umjesto (ض) korišten je grafem (ظ): 24b/1: farz (فرظ). U ovom primjeru možemo vidjeti da se radi o zamjeni grafema.

Kod riječi 25b/16: hazer (حاظر) umjesto (ض) zabilježeno je (ظ), dok je u jeziku izvorniku (حاضر).

U nekim primjerima umjesto (ظ) imamo grafem (j): 25a/7: zalim (jالم) u rječniku se bilježi kao (ظالم). Potom u tekstu na mjestu 27b/12 bilježen je zalum (زالوم), a u jeziku izvorniku se bilježi kao (ظالوم).

Kod mnogih primjera uočljivo je grafijsko bilježenje dugog vokala $a$ elifom (!) tamo gdje nije potrebno:

24b/6: namaza (ناماز), 28a/19: namazu (نامازو). Ovdje možemo vidjeti da je autor, vjerovatno oslanjajući se na maternji jezik, upotrebljavao elif za bilježenje dugog vokala $a$ na svim mjestima kod riječi namaz (نماز).

25b/9: ragbet (راغبت). Riječ ragbet (rağbet) u jeziku izvorniku se bilježi bez elif (I), pa i za ovaj primjer možemo reći da mu je razlog vjerovatno autorovo nedovoljno poznavanje arapskog jezika ili pak slučajna brzopletost koji su doveli do drugačijeg grafijskog bilježenja grafema orijentalnog porijekla. Još jedan od razloga drugačijeg bilježenja je eventualno i taj što se radi o fonetskom načinu pisanja riječi koja se ustabilila u bosanskom jeziku (رغبت).

U tekstu na stranici 26b/11 stoji: gajet (غنه ت), a u jeziku izvorniku se bilježi gajet (غايت).

Riječ vakt koja se bilježi u tekstu na stranici 27a/12: vaktom (وقاقوم), u jeziku izvorniku bilježila se bez elif ('), tj. (وقتوم).

27b/2, 3, 5, 7: b̂̀-namaz (بناماز). U rukopisu se na nekoliko mjesta spominje riječ namaz čiji je grafijski oblik u većini slučajeva identičan kao i 
onaj u jeziku izvorniku, međutim, u primjeru koji je spomenut na četiri mjesta u ovom rukopisu ova riječ je zabilježena drugačije. Ova riječ u jeziku izvorniku se bilježila kao bî-namaz (بنماز). U primjeru koji se navodi u 27b/11 možemo vidjeti da je ista riječ bilježena na drugi način u odnosu na onaj spomenuti (بنامز).

27b/8: kasab (قصب). Izvorno grafijsko bilježenje ove riječi orijentalnog porijekla je (قصاب).

27b/10: zarar (ذارار). U arapskom jeziku riječ zarar se grafijski bilježi na ovaj način (ضرر).

30a/17: saraj (سار ایى). U ovom primjeru možemo vidjeti da je riječ saraj, koja je inače riječ perzijskog porijekla (seray), u pjesmi Kitab-i bosnevi napisana drugačije u odnosu na jezik izvornik (سر ایى).

27b/8: dušmanin (دوشمانين); 31a/17, 30b/17: dušman (دوشمانين). Riječ dušman koja je iz perzijskog jezika prešla u turski, a potom i u bosanski jezik i koja se danas, također, svakodnevno koristi u našem jeziku, grafijski se bilježi ovako (دوشمن).

30b/2: rahat (راحات). Kao što se može i primijetiti, grafijsko bilježenje i ove riječi je drugačije u odnosu na jezik izvornik jer je glas elif (।) napisan tamo gdje se u jeziku izvorniku kod pisanja ove riječi ne bilježi. Također, identičan slučaj je kod primjera 30b/9: hasta (حاستا). Ova riječ u jeziku izvorniku se piše (خشته).

29a/8: salavate (صلاواة). Još jedna riječ orijentalnog porijekla koja se zbog svog religijskog karaktera koristi u bosanskom jeziku, kao i u jezicima orijentalnog porijekla. $U$ arapskom jeziku ova riječ grafijski se bilježi u jednini (صلوات).

U rukopisu Kitab-i bosnevi riječ sakat sa nastavkom -om u tekstu na 30a/13 se bilježila kao (ساقاتوم), a u jeziku izvorniku bilježenje riječi sakat je bez nastavka (سقط). Kod riječi 27b/9: mahali (ماحم) vidimo odstupanje u odnosu na jezik izvornik (محال).

24b/7: ramazan (راماضان). Ovdje je, također, uočljivo drugačije bilježenje ove riječi u odnosu na jezik izvornik. Do drugačijeg bilježenja je došlo po svemu sudeći iz jednog razloga, a to je da autor ovog djela nije 
baš najbolje poznavao grafiju riječi orijentalnog porijekla, što je donekle i prihvatljivo, jer je bio stranac. Grafijsko bilježenje riječi ramazan u jeziku izvorniku je (رمضان).

Kod primjera 28a/5: šejtan (شيطن) vidimo da je izostavljen elif (') u pisanju. Grafijsko bilježenje ove riječi u jeziku izvorniku je sa elif (شيتان). Dugi vokal $i$ (ي) napisan je tamo gdje, prema jeziku izvorniku, ne bi trebalo.

26b/6: džahila (جاهيلا). Ova riječ izvedena je od arapske riječi, a prema turskom pravopisu cehl-cehalet, pa od toga i džahil (cahil (جاهل)) što u prevodu znači neznalica. Ovdje vidimo da je autor, vjerovatno oslanjajući se na pravopis koji se koristio u to vrijeme, prilikom bilježenja riječi orijentalnog porijekla u bosanskom jeziku koristio dugi vokal $i$ (ي), što je naravno u odnosu na bilježenje u jeziku izvorniku znatno drugačije.

U nekolicini primjera vidimo grafijsko bilježenje dugog vokala $u$ (و) tamo gdje u jeziku izvorniku nije zabilježeno:

25b/18: zulum (زولوم). U ovom primjeru možemo vidjeti da je grafijsko bilježenje riječi zulum, prema bilježenju iste riječi u jeziku izvorniku, drugačije u odnosu na primjer u tekstu. U jeziku izvorniku se bilježi (ظلم).

30a/13: dunjaluk (دونالوقو); 31/a03: dunjaluku. U bosanskom jeziku ova riječ je svakodnevno prisutna, a u naš jezik došla je posredstvom osmanskog, odnosno turskog jezika. Iako je arapskog porijekla, trebamo napomenuti da je ova riječ u turskom jeziku često korištena sa raznim glagolima. Ova riječ se u jeziku izvorniku bilježila kao (دنيا).

U primjerima 31b/9: vedud (ودد) i 31b/13: kuddus (قد س) moguće je da je riječ o previdu ili o autorskoj nedosljednosti u pisanju. Prilikom grafijskog bilježenja prvog primjera izostavljena je oznaka kojom se bilježi glas $u$ (ودود) (ود). Kod drugog primjera da se primijetiti da je prilikom

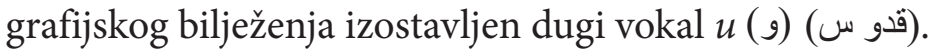

31b/16: mudžib (مجيب). Kod grafijskog bilježenja riječi mudžib imamo odstupanje na dva mjesta u odnosu na jezik izvornik (موجب). U odnosu na jezik izvornik, nije bilježen dugi vokal $u$ koji se obilježava sa (و), ali je 
umjesto toga bilježen dugi vokal $i$ (ي), koji opet nije zabilježen u izvornom obliku ove riječi. Mudžib se u jeziku izvorniku grafijski bilježio kao (موجب).

U nekim primjerima izostavljeno je grafijsko bilježenje glasa ayn (ع) ili je u pisanju zamijenjeno nekim drugim glasom.

29a/9: ibadet (ايبادت). Riječ ibadet u jeziku izvorniku grafijski se bilježila sa ayn (عبادت).

Grafijsko bilježenje glasa ( $)$ opisujemo u sljedećim primjerima:

26b/10: ahiretom (آخربنوم), od arapske riječi ahiret (آخرت). U ovom primjeru ako zanemarimo nastavak -om koji se koristi u bosanskom jeziku, možemo primijetiti da samu riječ ahiret autor piše bilježeći grafem (०).

25b/4: nimete (نعمه تنه). Grafijska oznaka riječi nimet koja je, inače, arapskog porijekla, a koja se koristi i u turskom, kao i u bosanskom jeziku je (نعمت).

25b/10: devletu (ده ولنو). Grafijsko bilježenje ove riječi prema jeziku izvorniku bilo bi bez grafijske oznake (०).

26b/11: zebanije (زه) بانية). Ova riječ, arapskog porijekla, u rječniku se bilježi kao (زباني).

29b/8: meleć (مه لله ك) Srafijsko bilježenje ove riječi prema jeziku izvorniku je (ملك), a kod primjera 31b/14: rešid (ره شيد) navodi se (ر شيد).

U jednom primjeru umjesto (ص) zabilježeno je (ض).

Rijedak primjer u kojem se bilježilo (ق) umjesto (5).

Na specifičan način bilježene su i riječi u sljedećim primjerima:

25b/1: Rizullah (الله رداء). U ovom primjeru da se primjetiti da je autor grafeme bilježio drugačije u odnosu na jezik izvornik (رضى الله).

28b/1: fani (فان) je još jedna riječ orijentalnog porijekla koja se preko turskog jezika koristila u bosanskom jeziku, a u jeziku izvorniku se piše (فانى). 
28b/7: belaja (به لايا). Grafijsko bilježenje riječi belaj koja dolazi od arapske riječi bela je (بلاء).

30a/10: šerbe (شربه).U turskom jeziku riječ şerbet (شربت) preuzeta je iz arapskog jezika i to od riječi šurb, dok se u bosanskom jeziku koristi kao riječ orijentalnog porijekla u kojem vidimo da dolazi do ispadanja glasa $t(\bullet)$.

31a/10: rezak (رزاق). Kod grafijskog bilježenja ove riječi nedostaje znak koji označava šedde iznad glasa $(j)$.

27b/14, 28a/10: šeriat (شر عت). Grafijsko bilježenje riječi šeriat u arapskom jeziku, iz kojeg je preko turskog, odnosno osmanskog jezika došla i zadržala se u bosanskom jeziku jest (شريعت).

24a/21, 31a/2: ebedi (أَبَبيّ). U ovom primjeru, ako uporedimo jezik izvornik, možemo vidjeti da je autor, iako je koristio sekundarne znakove za bilježenje vokala, što nije bilo slučaj ranije, napravio odstupanja tako što je bilježio vokal $i$ kratkim znakom, umjesto znakom koji označava dugi vokal (أبدى), što možemo da vidimo u primjeru na 31a/3.

Riječ sabır u turskom jeziku, koja je preuzeta iz arapskog jezika sabr (صبر), u ovom rukopisu zabilježena je kao 30b/10: saburim (سابوريم), ali kao što smo mogli i primijetiti, grafijski je bilježena drugačije u odnosu na jezik izvornik.

31a/8: belaj (بلاى). Riječ bela (بلاء) koja je iz arapskog jezika preko turskog, odnosno osmanskog jezika došla u bosanski jezik, ima značenje "belaj, nedaća, nevolja, muka, tegoba, patnja, bol".

Kod riječi 30a/15, 31b/14: đunah (جوناح), 31a/5: dunahe trebamo spomenuti da je ova riječ u perzijskom jeziku grafijski bilježena kao gunâh (كناه), u turskom günah, a u arapskom jeziku cunâh.

U primjeru 24a/12: đovde (جووده), u riječi koja se u turskom jeziku bilježi kao gövde vidimo da je ovdje bilježen glas (ج).

U riječi 30a/8: mehtef (مه خته ف) umjesto (ك) bilježilo se (خ) ), te umjesto (ب) pisalo se (ف), što je u odnosu na arapski jezik poprilično odstupanje. U arapskom jeziku ova riječ se grafijski bilježi (مكتب). 
Afrikata ć se u primjerima 31a/18: ćar (جار); 31a/16: ćaru (جارو) i 31b/1: ćarom (جاروم), ne bilježi s (ك), kao što se može i vidjeti u jeziku izvorniku.

\section{Transkripcija teksta Heze Kitab-i bosnevi ${ }^{3}$}

Bismillahi-r-rahmani-r-rahim

(1) Dobar poso ti počimaj bismilom,

(2) Kolaj će ga Bog učinit istinom.

(3) Vazda uči ti jezikom hamd Bogu,

(4) Salavat će grijehe oprat paš dobro.

(5) U pamet se ti obur,

(6) Dunjaluka ne miluj. Jedan Allaha ti viruj,

(7) Više nikog se ti ne boj!

(8) Sve stvorio i sve stvara kadar Allaha

(9) Ti vjeruj! Jedan Allah bez postanka,

(10) Bez nestanka.

(11) Nima majke ni ortaka, ti viruj!

(12) Nima đovde ni sureta ni mjesta.

(13) Ni prilike ni nalika, sva što znade Bogu ništa ne treba,

(14) Sve bi sifat-i kemal su mu, ti viruj!

(15) Prav je Kur'an, od Allaha ti viruj,

(16) Pejgamberu i insanu poslan je, ti viruj

(17) Muhammed je Hak Pejgamber svakomu: ${ }^{4}$

(18) Melaiću, insanu i džinu. Što je u dinu Allah kazo je, vjeruj!

(19) Iz Kur'ana Pejgamber, sve viruj.

(20) Ko viruje naš Pejgamber što veli,

(21) U džennetu biće vazda ebedi.

3 Transkripcija rukopisa Kitab-bosnevi je prilagođena modernim normativnim rješenjima u smislu dodavanja tački, zareza, razdvajanja klitika od tonične riječi itd.

4 Dopisano naknadno Ibrahim 
(24b)

(1) Odmah nama farz je svakom robu zinat

(2) Naučiti ilmihal.

(3) Ko po ilmihal radi, od taga je Allah razi

(4) Na dva svijeta daće mu selameta Allah.

(5) Ilm uči i slušaj, ti brezposlan ne hodaj!

(6) Pet namaza sve klanjaj!

(7) Posti vazda ramazan.

(8) Ćabbi iđi, zećat daj,

(9) Od insa biž u kraj!

(10) Po ćosanju ne sentaj!

(11) Od hajra ne ostaj!

(12) I malo se ne varaj, na magruru ne bivaj! ${ }^{5}$

(13) I u lov se ne vucaj,

(14) Te za psima ne pristaj!

(15) S pjanciama ne hodaj,

(16) Dedovine ne prodaj!

(17) Farz što ti je ne ostavljaj,

(18) Od harama ti se čuvaj!

(19) Ćibr čine takva čuvaj!

(1) Selameta duši gledaj,

(2) Lijepe čudi sve ti primaj!

(3) Ružne huje ne uzimaj,

(4) Šućur čini kad je kolaj!

(5) Sabur čini kad je belaj,

(6) Pahluk nefsu dobro podaj!

(7) Zalim nefsu dizgin ne daj,

(8) Amel čini, sunnet gledaj!

(9) Gaflet digni ter pogledaj,

(10) Za din islam dušu podaj!

5 Dopisano naknadno na, kao i znakovi koji se koriste prilikom pisanja kratkih vokala u arapskom pismu. 
(11) Bez hesaba Džennet faćaj!

(12) Ko je šehida i gazija, u Džennet će bez ${ }^{6}$ hesaba!

(13) Sevab hoćeš tijelo muči,

(14) Džefa nikom ti ne čini!

(15) Hakkom na hak ti ne čini,

(16) Hajr što je ono čini!

(17) Zem nikoga ti ne čini,

(18) Sve kada tamam čini!

(25 b)

(1) Rizullah taleb čini,

(2) Sve hvalu Bogu čini!

(3) Osim Boga nima dosta,

(4) Stvara sve nimete.

(5) Što Bog hoće sve će biti,

(6) Ah, nemoj se ni s kim biti!

(7) Ured ćemu Allah dati,

(8) I tebi će sevab biti.

(9) Ragbet čini šeriatom bićeš,

(10) Sve jeziku ti devletu svašto pitaj.

(11) U dealima pravo će ti kazivati,

(12) Od halala blago teći, sevabıma.

(13) Lasno ti je turčin biti,

(14) Ko Bog veli robovati.

(15) Ilmihalom kazakala tebi je robovati,

(16) Hazr turke ne vraćati.

(17) Ilmihalom ne vraćati,

(18) Nemoj nikom zulum mislit.

(1) Od Boga ti ne tra ${ }^{7}$ ži ćerameta,

(2) Već ti traži ibadeta.

6 Dopisano bez.

7 U tekstu je naknadno dopisano tra-. 
(3) Dobar turčin hoćeš biti,

(4) Vala srce očistiti.

(5) Bogu širka ne činiti,

(6) Srcu jezik ugoditi.

(7) Grijeha se pokajati,

(8) Na grijeh se ne vraćati.

(9) Dragom Bogu robovati,

(10) Robovati je ljepota.

(11) Ne poslušat grijehota,

(12) Odveć vrlo sramota. ${ }^{8}$

(13) Što nijjetiš sve Bog zna,

(14) Na pomuki sve nijaz.

(15) Sve znat vala od Boga,

(16) Zaboravit drugoga.

(17) Šućur čini daima,

(18) Iza muke last ima.

(19) Ovi svijet sad će proć,

(26b)

(1) Po dušu će meleć doć,

(2) La ilahe illallah.

(3) Ako hoćeš ti u Džennet, sevab radi,

(4) Grijeh ne radi.

(5) Od grijeha i ćufra (?) biće

(6) U džahila sastanu se sama.

(7) Grijeh rade um gube,

(8) Umom se Džennet tiče.

(9) Svojoj duši,

(10) Ne brinu se za ahiretom.

(11) Gajet čega kinet zebanije,

(12) Čuvaj dušu svoju i svoj amel.

8 Radi lakše čitljivosti čitav red je ponovo napisan rukom. 
(13) A dunjaluk neka ga, boljeg ništa i nima,

(14) Da li znadeš šta ima?

(15) Zborijo bi da ima,

(16) Srcu voma opere turkovanje otare.

(17) La ilahe illallah Muhammedun resulullah, sve uči

(18) Svoga nefsa poturči.

(27a)

(1) Ti nikoga ne muči, uzmi Kur’an pa uči.

(2) Belli tedžvid farza ti uči, ti krivo ne uči!

(3) Elif harf pravo uči,

(4) Jedan drugom ne priliči.

(5) I što umiješ vazda uči,

(6) Šejtana ćeš otjerati.

(7) Allah će te sačuvati,

(8) I sevabe će ti dati.

(9) I ko Boga viruje,

(10) Pejgamber ga miluje.

(11) Neka iđe na namaz, u Kur'anu zapovijed,

(12) Svakom robu turčinu vaktom na namaz.

(13) U Džennetu mjesto mu je

(14) U Džennetu mjesto mu je ko god čisto uzhoda.

(15) Na komu je tursko ime neka iđe na namaz,

(16) Ako namaz sve uzklanja naš ko da radi sve sevabim

(17) Hajde braćo da

(18) Iđemo džematom da klanjamo.

(27b)

(1) Turkovanje da činimo, od grijeha pać budemo!

(2) Ono ti je bî-namaz nefsa i šejtana ne slušaj.

(3) Što ti veli ne klanjaj, u pako će bî-namaz,

(4) Hodi, ago, ti klanjaj i nauči ilmihal! 
(5) Ter ne budi bî-namaz,

(6) Ko ne iđe u džamiju, već bježi u avliju,

(7) Čok mel-un je bî-namaz,

(8) U kasab seljanin, to je dušmanin golem.

(9) Ko ne ide na namaz, u mahali ne klanjač,

(10) Od toga je čo zarar.

(11) Hijanet je bî-namaz, kada ezan zauči,

(12) Koji neće na namaz, čok zalum je bî-namaz.

(13) Virovanje pravo drži,

(14) I šeriat dobro traži!

(15) Allah nama zapovijedi,

(16) Hem Pejgamber ismerledi.

(17) Da bijaše išta ljepše,

(18) Pejgamber bi haber dao.

(28a)

(1) Baš evlija ono ti je ko šeriat,

(2) Dobro pazi, sve ćitabom Allah kazo.

(3) Ko je turčin, šubhe nima, od šubhe se dobro čuvaj,

(4) Vesvesama ne ujiši.

(5) Jer je šejtan velik dušman,

(6) Grijehe vazda oslađiva, na grijehe

(7) Vazda mami insane.

(8) Vazda uči Estagfirullah!

(9) Laf ne čini i ne laži,

(10) Jer šeriat neće laži.

(11) Od Kur’ana i od hodža ne biži,

(12) Iz mahredža harfe nauči i kaži ne fali se.

(13) I šuhrete ne traži

(14) I što znadeš, sebi dobro dokaži.

(15) Dok si živ sevab radi

(16) I traži, kad umreš u mezaru ne traži. 
(17) Zićrullahom srce užeži,

(18) Drugim lijepo srce ne žeži!

(19) Zićrullah je u namazu,

(20) Nabuci.

(1) Djalo fani haseda neki,

(2) Od azaba i straha plači.

(3) Iman će ti i bereket biti veći,

(4) Tedžvid Kuraan virlo ti je najpreći.

(5) Kur'an će te u džennet uvesti.

(6) Ti pođu ti pravo Boga moliti.

(7) Vazda će te od belaja čuvati,

(8) I pohiti vaktom vazda klanjati.

(9) Namaz će te u džennet uvesti.

(10) Radi dina učite,

(11) Svaki sebe turčite.

(12) Čistim srcem svako može.

(13) Da nam Bog pomože.

(14) Ko Pejgamber kaže, klanjaj

(15) Od grijeha se uklanjaj,

(16) Izrad sebe zaboga!

(17) Jer Džehennem zla je vatra,

(18) Pun je zmija i akrepa!

(29a)

(1) Teško onom ko uniđe, odveć azab,

(2) Čini čega osim umrijet, Allah ne da veće osim ostati ebedi.

(3) Vazda šejtana lagat će ti,

(4) Turkovanje mučno činiti.

(5) Da u paklu voma bude, ne slušaj ga, zaboga!

(6) Ko ne klanja, pun je grijeha, haram mu je i što jede

(7) I što pije i što nosi, ko je turčin sevap radi

(8) Hajr dovve i salavate. 
(9) U džamiju za ibadet,

(10) Bog nam dade svaki devlet, smrt je istina

(11) Gore ta je šerbet, svak će njega popit

(12) Elbet, pa će svojom hesab viđat.

(13) Bogu dževab ti ćeš davat,

(14) Tevter ćitab ti ćeš učit.

(15) Neće moći izučiti,

(16) Već će se namučiti.

(17) Čuvajte se, zaboga,

(18) Od grijeha svakoga!

(19) Da nam Bog da se njegov rahmet

(29b)

(1) I Pejgamber lijep šefaat!

(2) Kad ja pođoh u džamiju,

(3) Susrete me naš Pejgamber.

(4) Di me srete, tu mi reče:

(5) "Ovi svijet kano cvijet,

(6) Ovi insan bil behar.

(7) Puhnu ejjan, spade behar.

(8) Svakomu će meleć doći;

(9) I insanu i hajvanu,

(10) I trčeći u gorici,

(11) I ribici u vodici."

(12) I nama će smrt doći,

(13) U mezar se zatvoriti.

(14) U mezaru ni pendžer, da mi Bog da kabr pendžer.

(15) Bog mi dade kabr pendžer,

(16) Da ja gledam po Džennetu po devletu.

(17) U Džennetu jedna bašča,

(18) U toj bašči jedno drvo,

(19) Ime mu je Tuba drvo. 
(30a)

(1) Na njem ima svaka voćka,

(2) Hazur odveć vrlo slatka.

(3) Pod njim ima jedno vrelo,

(4) Ime mu je Kevser vrelo.

(5) Kod njeg sjede tri buljuka,

(6) Jedan buljuk sve džomerda.

(7) Drugi buljuk sve gazija,

(8) Treći buljuk sitne djece iz mehtefa.

(9) U ruci im po maštrafa,

(10) Kevser šerbe oni toče,

(11) Kevser šerbe poje svoje majke i babajke,

(12) La ilahe illallah, ne prodaje se dunjaluka sakatom,

(13) Već ti kupuj sve džennetske lezzete!

(14) Grijeh ti džunah ne bude

(15) Džennet Bajram kad bude.

(16) Džennet saraj lipa kuća,

(17) Ko uniđe te srića.

(18) U njem umrijet neće biti,

(19) Već će vazda ostanuti.

(30b)

(1) Pravo radite, turci,

(2) I učite da budete rahat onđe.

(3) Al još veće, vidjet Boga, devlet nima iza toga!

(4) Ko je tučin bijo ovđe, sve ljepote nađe nođe.

(5) Allah reče: "Radi hajrat,

(6) Biće tebi beli Džennat!"

(7) Ko je ašik, on se brine,

(8) Sve najviši sevab radi.

(9) Što sam fakir i hasta sam, ne velim,

(10) Turci bismo, razi bismo, saburim. 
(11) Ah sevabe harove najvolim,

(12) Ja boljega dunjaluka ne tražim.

(13) U Kuranu, u ćitabu rečeno

(14) Nek je tijelo ibadetom mučeno.

(15) Mostarlija tebi kaže učeno,

(16) Na mahšeru da ne bude mučeno.

(17) Ko grijehe radi svoj je dušman,

(18) Š njim je pobro, bio šejtan.

(19) Ko se Boga ne boji,

(20) Od hajvana gori.

(31a)

(1) Ko je ćafir, od svašta je najgori,

(2) U paklu je u sindžiru ebedi.

(3) Što Allah veli, bez šubhe će u Džehennem ebed.

(4) Vako veli naš Allah: "Blago onom ko ne znah,

(5) Dobro Omer vjeruje da nam Allah sve đunahe pokloni,

(6) U Džennet se metne." Amin. Dua-i Bosnevi.

(7) Što ti pišem, o dina sve ti znaj,

(8) Na din islam, ko ti laže, Allah će mu dat belaj.

(9) Šućur Bogu na svačemu, moj Allah

(10) Tebi šućur na nimetima, ja rezak

(11) Sala selam na sve Džennet, ja selam

(12) I na alime i na sve turke, ja gaffar

(13) Tebi moću dojše nima, ja Allah

(14) Tebi zuhr sve je munevver, ja Rabb

(15) Kad je tako nismo pišman, ja kerim

(16) Fahr turskom ćaru nusret podaj, ja vehabb

(17) Dušman mu učini, ja fehhar

(18) Sve mu svijetu ti si ćar sada.

(1) Naš Abdulaziz Boga je metno ćarom baš,

(2) Gafele nam ti propo, (?) fettah, 
(3) Muško žensko ti uputi

(4) Na to posve za kibre ukabuli, ja šućur

(5) I abdest (?), ja Rabb ${ }^{9}$

(6) Lazim ti je neće, ja dostom ${ }^{10}$

(7) Rahat safa tebi meni Džennetom steći,

(8) Smetat muka će ga, ja mabud ${ }^{11}$

(9) Kad imamo takog dosta, ja vedud ${ }^{12}$

(10) Nimam brige ničije danas, ja rahman

(11) S nefsom kavga i šejtanom, ja džebbar

(12) Čuvaj lice svome dinu, ja kajjum

(13) Pomozi nam vazda vazda, ja kuddus

(14) Od meni grijehe i đunah, ja rešid

(15) U tebi je velik rahmet, ja rahim

(16) Ukabuli naše dove, ja mudžib

(1) Tvojim farzom, ja rahmani -r-rahim

(2) Salli ve sellim ala resulina Muhammed ve ala alihi edžmein

(3) Vel-hamdu lillahi Rabbil-alemin.

(4) El-Fatiha.

(5) Sume nuzifehu biizniallahi teala.

(6) Temmet.

(7) Allahume, salli ala sejjidina Muhammedin ${ }^{13}$

(8) Allahume, salli ala sejjidina Muhammedin

(9) Salaten tundžina biha min džemil el-ahval

9 Sa strane rukom dopisano Ali Dervišević

10 Dopisano Trako Mustafa

11 Dopisano Adem bin Natif

12 Također, u rukopisu se može vidjeti da je naknadno dopisano i mjesto Visoko Bosna.

13 Naknadno dopisano 


\section{Zaključak}

U radu su razmotrene ortografske karakteristike rukopisa Kitab-i bosnevi iz Zbirke bosanske alhamijado književnosti sa pojedinim arapskim tekstovima za koji se pretpostavlja da potječe iz XIX stoljeća. Analizirale su se fonetsko-fonološke karakteristike, odnosno odstupanja od pravopisa kod bilježenja riječi domaćeg, a naročito orijentalnog porijekla. Jedan od glavnih razloga odstupanja od pravopisa je svakako autorovo nedovoljno poznavanje grafijskog bilježenja glasova turskog i arapskog jezika. Na nekim mjestima u tekstu utvrđen je dvojak način pisanja grafema koji imaju iste glasovne vrijednosti, što se moglo vidjeti i kroz primjere koje smo izdvojili i za koje smo ponaosob naveli ispravno bilježenje. Neki primjeri su posljedica miješanja govornog jezika i dijalekatskih osobina govora koji je bio prisutan u to vrijeme. Veoma su interesantni i primjeri koji su iz turskog, odnosno arapskog jezika prešli u bosanski jezik i koji su kao takvi, uz dodavanje određenih morfema, nastavili da se koriste. Alhamijado pismenost u Bosni je sigurno jedna od pravih vrijednosti koje bi trebalo detaljnije istražiti i očuvati njen značaj.

\section{Literatura}

Abdović, Abdullah (1901): Zbirka bosanske alhamijado književnosti sa pojedinim arapskim tekstovima, prepisivač Ibrahim Šehović, Nacionalna biblioteka u Beču, registarski broj 1681, Beč.

Baćićanin, Fuad (2016): Preplitanje kultura na tlu Srbije u Osmansko doba - na primjeru alhamijado književnosti, doktorska disertacija, Univerzitet u Beogradu, Filološki fakultet, Beograd.

Drkić, Munir; Kalajdžija, Alen (2010): Sehletul-Vusul / Omer Hazim Humo. Grafija i leksika Sehletul-vusula, Muzej Hercegovine, Mostar.

Filan, Kerima (2000): "Ortografske karakteristike Ljetopisa Mula Mustafe Bašeskije”, Prilozi za orijentalnu filologiju 49, Orijentalni institut, Sarajevo, 19-43.

Huković, Muhamed (1986): Alhamijado književnost i njeni stvaraoci, Svjetlost, Sarajevo. 
Kalajdžija, Alen (2019): Predstandardni idiom bosanske alhamijado literature, Radovi 24, Institut za jezik Univerziteta u Sarajevu, Sarajevo.

Korkmaz, Zeynep (1995): “Eski Anadolu Türkçesinde İmlâ-Fonoloji Bağlantısı Üzerine Notlar”, Türk Dili Üzerine Araştırmalar, Birinci Cilt, Ankara, 491-505.

Šabanović, Hazim (1973): Književnost Muslimana BiH na orijentalnim jezicima, Svjetlost, Sarajevo. 


\title{
Study about the manuscript Kitab-i Bosnevi from the Collection of Bosnian Alhamijado Literature with Certain Arabic Texts
}

\begin{abstract}
Introduction: The poem Kitab-i bosnevi is just one of several that represents a compilation of moralistic alhamijado poems. They are collected in one Collection of Bosnian alhamijado literature with individual Arabic texts. The aim is to determine orthographic features through orthographic and phonetic-phonological analysis of the manuscript Kitab-i bosnevi, supposed to date from the 19th century, show how the author wrote words of domestic origin and recorded terms of oriental origin taken from Arabic and Persian. Detailed orthographic analysis of words of domestic and oriental origin was emphasised in the poem Kitab-i bosnevi. The Viennese version of the part of Sehvetul-vusul, by Omer Hazim Humo, offered us more precise insight into the characteristics of writing alhamijado literature. Words of oriental origin were recorded by respecting their way of writing concerning the original language. In some examples, there were deviations where the author offered a completely different way of recording certain voices. Based on the phonetic-phonological analysis of the song Kitab-i bosnevi, specific voices are entirely adapted to the phonetic system of the Bosnian language.
\end{abstract}

Key words: alhamijado, Kitab-i Bosnevi, XIX century, phonetic-phonological analysis

\section{Izjava autora o nepostojanju sukoba interesa i poštivanju općih etičkih kodeksa:}

Autor potvrđuje da ne postoji nikakav stvarni ili mogući sukob interesa vezan za ovaj tekst te da je tekst napisan u skladu s etičkim kodeksima prema preporukama COPE (Committee of Publishing Ethics). 